\title{
Resource productivity and resource use efficiency in wheat production
}

\section{P. U. KAUTHEKAR, B.R. PAWAR AND R. A. KOLAMBKAR}

Received : 30.05.2015; Revised : 09.08.2015; Accepted : 10.09.2015

\begin{abstract}
Investigation was carried out during the year 2013-14. About 48 irrigated farms were randomly selected from sixteen villages of two tehsils in Nanded district of Maharashtra. Data were related to wheat output and input like human labour, bullock labour, machine labour, seed, fertilizer, plant protection and irrigation as resources. Cobb Douglas production function was fitted to the data. The result revealed that partial regression co-efficient of human labour was 0.403 followed by that area under wheat was $(0.223)$ and irrigation $(0.221)$ which were positive at 5 per cent level. Patrial regression co-efficient of bullock labour, seed, nitrogen and potash were positive but non-significant. Marginal product of area under wheat was 6.694 quintals followed by that of bullock labour $(0.405 \mathrm{q})$, human labour $(0.354 \mathrm{q})$ and potash $(0.122 \mathrm{q})$. MVP to price ratio with respect to nitrogen was 10.71 followed by potash (8.70), human labour (4.31) and irrigation (2.53). Optimum use of area under wheat was found to be 1.24 hectares and optimum use of irrigation was $2268.06 \mathrm{~m}^{3}$.
\end{abstract}

KEY WORDS : Wheat, Resource productivity, Marginal productivity, Optimum resource

How to cite this paper : Kauthekar, P.U., Pawar, B.R. and Kolambkar, R.A. (2015). Resource productivity and resource use efficiency in wheat production. Internat. J. Com. \& Bus. Manage, 8(2) : 195-198.

\section{MEMBERS OF THE RESEARCH FORUM}

Correspondence to:

P. U. KAUTHEKAR, Department of Agricultural Economics, College of Agriculture, Vasantrao Naik Marathwada Krishi Vidyapeeth, PARBHANI (M.S.) INDIA

Email: pandurangk15@gmail.com

Authors' affiliations:

B. R. PAWAR AND R. A. KOLAMBKAR, Department of Agricultural Economics, College of Agriculture, Vasantrao Naik Marathwada Krishi Vidyapeeth, PARBHANI (M.S.) INDIA

Email: kolambkar.rachana14@gmail.com 